\title{
Energy production analysis of Common Reed - Phragmites australis (Cav.) Trin.
}

\author{
Jaroslav Demko ${ }^{1}$, Ján Machava ${ }^{2 *}$, Miroslav Saniga ${ }^{1}$ \\ ${ }^{1}$ Department of Biology and Ecology, Faculty of Education, Catholic University in Ružomberok, \\ Hrabovská cesta 1, 03401 Ružomberok, Slovak Republic \\ ${ }^{2}$ Institute of Transdisciplinary Environmental Studies, Faculty of Education, Catholic University in Ružomberok, \\ Hrabovská cesta 1, 03401 Ružomberok, Slovak Republic
}

\begin{abstract}
Demko, J., Machava, J., SANiga, M., 2017. Energy production analysis of Common Reed - Phragmites australis (Cav.) Trin. Folia Oecologica, 44: 107-113.

Slovakia is a country with limited natural resources, therefore its essential task is to search for new renewable sources of energy to reduce its dependence on imported fossil fuels. The results of research confirmed that the Common Reed (Phragmites australis (Cav.) Trin.) has considerable potential of phytomass production and energy storage (calorific value reached $17,448 \mathrm{~J} \mathrm{~g}^{-1} \mathrm{~d}$.w.). Biomass production of Common Reed under natural conditions of the lower Liptov region reached 12.702 tons of a dry mater per hectare with the calculated energy storage of $221.622 \mathrm{GJ} \mathrm{ha}^{-1}$. The average biogas production was $351.311 \mathrm{~kg}^{-1}$ of a dry matter of which the methane $\left(\mathrm{CH}_{4}\right)$ content represents $185.211 \mathrm{~kg}^{-1}(52.72 \%)$. With regards to the values of combustion heat, a calorific value and the production of methane it can also be noted that in case of Common Reed it is more profitable to focus on direct combustion of biomass than the production of biogas and methane.
\end{abstract}

\section{Keywords}

Common Reed, growth and energy parameters, production, phytomass

\section{Introduction}

Production of renewable energy belongs to the main objectives for the 21 st century. The production of biomass energy is one of the three methods used to obtain renewable energy (FARKAs et al., 2009). Because Slovakia is a country with limited natural resources, its essential task is to search for new renewable sources of energy to reduce its dependence on imported fossil fuels.

Globally, renewable energy sources are a new sustainable path to produce power. Although new sources of energy are still discovered in the form of fossil fuels, especially crude oil and gas, they are still anyway lim- ited even though they may be available to mankind for a long time. Over $80 \%$ of all the primary energy in the world is produced from fossil fuels. Crude oil accounts for over $35 \%$, coal for $26 \%$ and natural gas for $21 \%$ (IEA, 2008). All fossil fuels are finite and non-renewable natural resources limited either physically or economically (SUSLICK and MACHADO, 2004). This comes from the fact that it has taken millions of years for fossil fuels to be formed and now they are extracted rapidly.

Time of renewable energy sources has come, and their practical use depends only on the progress of science, human skills and political decisions. The range of renewables is relatively wide and the use of different types of renewables will mainly depend on the geo-

*Corresponding author: e-mail: jan.machava@ku.sk 
graphical, climatic and economic opportunities of individual regions or countries.

Biomass as a renewable energy source will certainly play an important role in the Central European conditions. It should be noted that the time of use of large energy resources is over due to the unfavourable situation in the environment, greenhouse effect resulting in global warming and climate change (HööK et al., 2010). Questioning the application of renewable energy in practice is wrong and obsolete. Such a statement is incorrect because each renewable energy source has its importance especially in the public sphere and in the municipal sector, precisely because it should relate primarily to this public sphere or general interest.

The energy accumulated in plants was investigated for example in the species Dryopetris sp. (KovÁčoví et al., 1999; KuKLová et al., 2014a; KuKLová et al., 2014b; KuKLová et al., 2015), Rubus sp. (KuKLová et al., 2014b; KuKloví and KuKla, 2009; SÝKORA et al., 2009), Carex pilosa (Kováčoví et al., 1999) and Galium odoratum (Kováčová and SCHIEBER, 2002). More attention was paid to energy plants such as Hybrid sorrel - Rumex patientia $\times$ Rumex tianshanicus (MAGA and Piszczalka, 2006) and Miscanthus sp. (Kotrla and PrČÍk, 2012 a,b, 2013, 2014).

This paper focuses on the production-energy analysis of a Common Reed, which under certain conditions could extend the register of plant species suitable for energy purposes. Common Reed belongs to the geophytes and helophytes and most often grows on permanently waterlogged and under-flooded soils where excess water and lack of air is over all the year. Their roots have air (aerenchymatous) tissues that mediate the air supply to the root system. Helophytes are often characterized by coarseness and roughness what results in low digestibility for animals and cannot be used as feed. The most frequent cause of coarseness and roughness of the material is high lignin content that is an advantage for direct combustion because lignin has better energy parameters than cellulose.

Orientation of research and investigation of the energy-production parameters of Common Reed is given by the fact that this species is a cosmopolitan plant in temperate zone widely occurring in a variety of environmental, climate-soil conditions with high assumed potential of phytomass production and energy accumulation.

Energy plants examined up till now have got relatively high energy supply (Maga and Piszczalka, 2006; PrČ́́K and Kotrla, 2015; PospíšIl, 2013), but their growing is rather expensive, so the aim of this work is research on Common Reed, which usually grows on land lying fallow.

The main objective of this work is focused on finding the basic growth, production and energy parameters of Common Reed as a potential source of energy. This requires establishing the combustion heat, calorific value and production of biogas from the individual or- gans of the Common Reed (Phragmites australis (Cav.) Trin.). A partial research goal is to determine the dry mater production of Common Reed on the unit area.

\section{Materials and methods}

\section{Characteristic of studied species}

The Common Reed (Phragmites australis (Cav.) Trin.), Poaceae (grass) family, belongs to the genus that includes only four widely distributed species of large perennial grass with creeping underground rhizomes. It is a monocotyledonous perennial, deeply rooting plant. It reproduces generatively and vegetatively and based on its life form it belongs to the helophytes. The plant reaches a height of 1-3 m, sometimes more, in the tropics it can grow up to $10 \mathrm{~m}$ (BuRNIE et al., 2007). Leaf blades are linear lanceolate, gradually long and finely pointed, grey-green colour. Flower is oblong egg-shaped panicle at flowering strewn, violaceous colour, flowering in August depending on the climatic conditions, in warm areas even till October (BURNIE et al., 2007). Reed is water-intensive, thrives in warm climates, occurs in more drenched soils, and on the banks of waters and in the backwaters. It produces large crops on suitable habitats, such as stagnant or very slowly flowing water (root in depths up to about $1 \mathrm{~m}$ ), springs, wet meadows, marshes, waterlogged forests, sometimes drier habitats with rocky soil (abandoned sand pit, etc.). The reed has a fairly large distribution area, therefore as a cosmopolitan species in temperate zone it grows virtually all over the world except for the Arctic region, high mountains and some tropical regions. In the Slovak Republic, it occurs abundantly from lowlands to mountainous areas, however at higher elevations, panicles usually do not come into blossom. Generally, the reed is considered as an important material for the construction industry and the raw material for pulp production, but it also can serve as food or fodder.

\section{Assessment of production}

Production analysis was performed with a material taken from a naturally occurring stand of Common Reed in a cadastre of the village Liptovská Teplá near the right bank of the river Váh. Investigated areas were selected randomly so as to reflect objectively the actual growth conditions of the reed crop. The village Liptovská Teplá is situated in the north part of central Slovakia with a relatively cool climate.

To determine the mass of Phragmites autstralis species, the 5 sampling points were set out randomly and marked on the examined area in August 2014. The area of the five partial plots (MP1-MP5) established in reed vegetation ranged from 1.2 to $4.0 \mathrm{~m}^{2}$, in order to eliminate the heterogeneity of Common Reed plants in area. The second collection was done 
in October, to determine the change in the reed density over an autumn period. However, the sampling of plant stalks in this case was done randomly. Individual reed stalks collected were cut manually, using gardening shears at a height of $3-5 \mathrm{~cm}$ above the ground. The collected material was packed into sheaves and then weighed on a hanging scales Kern HCB 20K10 in the field $(20 \mathrm{~kg} / 10 \mathrm{~g})$. Common Reed individuals have been then separated into stalks, leaves and panicles, measured (with precision of $1.0 \mathrm{~cm}$ ), weighed in fresh state (with a precision of $0,05 \%$ ) and finally plant samples for laboratory analyses were dried to a constant weight at $85^{\circ} \mathrm{C}$ for 24 hours.

The results were recalculated for an area of $1 \mathrm{~m}^{2}$ and dry matter per one hectare. The obtained data were tested for normality, using the Kolmogov-Smirnov test. Normal distribution for length data was confirmed by p-values of 0.194 for MP1, 0.070 for MP2, 0.200 for MP3, 0.062 for MP4 and 0.099 for MP5 and 0.200 for weighted average length data.

\section{Assessment of energy}

The plant material for energy assessment consisted of approximately 40 stalks of Common Reed with a weight of around $10 \mathrm{~kg}$ collected randomly from miniplots in August 2014, separated into stalks, leaves and panicles, chopped to a length of $30 \mathrm{~cm}$ and transported to the laboratory. Two kilograms of plant material was applied for calorimetry determination and the rest for the biogas production.

In the laboratory, Phragmites australis samples were processed to determine combustion heat. At first, the dry matter of individual plant parts was determined drying an aliquot of plant material to a constant weight at $85{ }^{\circ} \mathrm{C}$ in the Selecta $\mathrm{P}$ drying oven for a period of 24 hours (respectively to constant weight). Then plant samples were milled using the Retsch Cross Beater Mill SK100 to a fine powder, approximately $1.0 \mathrm{~g}$ of samples was weighted on the scale Denver Instrument SI-234 with a precision of $0.0001 \mathrm{~g}$, squeezed into a briquette and dried again to a constant weight. After filling the pressure vessel of calorimeter with oxygen to a pressure of $3.0 \pm 0.2 \mathrm{MPa}$, the combustion heat was determined by means of an IKA C4000 adiabatic calorimeter (software C 402) and subsequently the calorific value was determined by subtracting the heat of vaporization of the water from the value of combustion heat, according to the STN EN 14918: 2010 (65 7410) Solid fuels. Determination of calorific value.

\section{Assessment of biogas production}

The actual course of the tests was carried out according to the VDI 4630 Standard (2006) in the State Institute of Agricultural Engineering and Biology, University of Hohenheim, Stuttgart. The values of the biogas pro- duced were recorded for 40 days and the biogas analysis was carried out. Analyses were performed in triplicate. The same applies to the reference and the blank sample.

$$
\frac{O D M C \text { substrate }}{\text { ODMC vaccination sludge }} \leq 0.5,
$$

where $O D M C$ is dry matter content.

The substrate of Common Reed was added to the fermentation vessel and mixed with water. The container was carefully filled with vaccination sludge in such an amount that the relationship between the substrate and vaccination sludge satisfies the following equation:

In this step, it is not necessary to work under $\mathrm{N}$ atmosphere (as referred in DIN EN ISO 11734, 1998), however an intense exchange with ambient air should be avoided. Prior to the fermentation the vessels are to be shut, in the gas phase they should be rinsed with nitrogen so as to remove residual oxygen from the gas phase. Due to the aerobic decomposition, the oxygen might have a negative effect on the yield of biogas. During testing a care should be taken so that the fermentation material was sufficiently mixed. Regular mixing (i.e. shaking vessels, daily re-suspension of sediment and floating layers), is required.

The amount of biogas was read out as frequently as necessary so that the course of the formation of gas was perfectly recognizable. This requires daily measurements at the beginning of the tests, if the daily output of gas decreases, the reading rate may be reduced to once every two or three days. The methane volume in biogas is determined at regular intervals. It is not sufficient to determine the amount of methane only once over the entire test, as the volume of methane differs significantly in the course of the fermentation test. The criterion for the test completion is the condition that the daily production of biogas accounts for only $1 \%$ of the total volume of biogas. Normally, most of the biogas is produced during the first week of a fermentation process. Fermentation test most often ends after 20-40 days, but the production of biogas is very low at the end of the test.

The amount of carbon generated by microbes is calculated as the increase in the gas net production and the net creation of inorganic carbon compared to the blank value. The biodegradation percentage is calculated from the total inorganic carbon generated and measured or calculated the amount of carbon added to the test substance. The course of biodegradation can be monitored only by running measurements of the gas production.

\section{Results}

\section{Production analysis of reed}

The arithmetic means of length of Common Reed individuals on the examined miniplots were $(\mathrm{cm})$ : 
MP1 279.3 \pm 4.9, MP2 317.5 \pm 5.4, MP3 262.1 \pm 6.0 , MP4 263.4 \pm 4.4 , MP5 $262.0 \pm 7.1$ and the arithmetic mean of all measurements was $269.1 \pm 31.2 \mathrm{~cm}$ (Table $1)$. The values found correspond to those reported in the literature, according to which the Reed stalks length ranges 1-3 $\mathrm{m}$ (BURNIE, et al., 2007). The arithmetic mean of stalk length of samples examined was $233.5 \pm$ $13.4 \mathrm{~cm}$ and of panicles $37.8 \pm 6.1 \mathrm{~cm}$.

Table 1. Length (cm) of Phragmites australis stalks

\begin{tabular}{ccccc}
\hline & \multirow{2}{*}{$\begin{array}{c}\text { Number of } \\
\text { individuals }\end{array}$} & Stalks & Panicles & Whole plant \\
\cline { 3 - 5 } & $(\mathrm{pc})$ & & Length $(\mathrm{cm})$ \\
\hline MP1 & 50 & $240 \pm 2.3$ & $39.3 \pm 1.9$ & $279.3 \pm 4.9$ \\
MP2 & 59 & $265 \pm 3.9$ & $52.5 \pm 1.3$ & $317.5 \pm 4.9$ \\
MP3 & 83 & $227 \pm 4.6$ & $35.1 \pm 1.5$ & $262.1 \pm 6.0$ \\
MP4 & 110 & $228 \pm 3.5$ & $35.4 \pm 0.9$ & $263.4 \pm 4.4$ \\
MP5 & 160 & $227 \pm 5.1$ & $35.1 \pm 1.5$ & $262.0 \pm 7.1$ \\
\hline Mean \pm SD & & $233.5 \pm 13.4$ & $37.8 \pm 6.1$ & $269.1 \pm 31.2$ \\
\hline
\end{tabular}

Based on the performed measurements it was confirmed that the mean weight of fresh stalks, leaves and panicles accounted for $61.2 \%, 27.5 \%$ and $11.3 \%$, respectively, of the whole plant weight $\left(0.25 \mathrm{~kg} \mathrm{pc}^{-1}\right)$. The dry matter of reed stalks, leaves and panicles in August 2014 represented 46.7\%, 44.9\% and 35.0\%, respectively. The analysis of reed dry matter was repeated towards the end of the growing season in the first half of October 2014 to identify changes in plants moisture depending on the season. This analysis resulted in obtaining the values: $51.9 \%, 48.8 \%$ and $48.7 \%$, respectively. The whole plant weight was therefore lowered approximately by about $15.0 \mathrm{~g}$ due to the evaporated water. Based on the foregoing facts, it can be concluded that the highest increase was observed in the dry mater of panicles $13.7 \%$, then follow stalks and leaves with $5.2 \%$ and $3.9 \%$, respectively. This fact can be general- ized in such a way that there was a slight (by 6.0\%) dry matter increase towards the end of the growing season, and it can be assumed that the highest dry matter content of the Common Reed will be at the end of the growing season and over the subsequent winter months.

The weight of fresh reed biomass was determined in such a way that all biomass from miniplots was collected, including necrotized parts of leaves, which may represent about $5-10 \%$ of all weight. The stock of fresh reed biomass per $1 \mathrm{~m}^{2}$ determined as an arithmetic mean of all research miniplots reached $2.83 \pm 0.79 \mathrm{~kg} \mathrm{~m}^{-2}$ (Table 2). Dry matter determined as a weighted arithmetic mean of plant individual organs is equal to $44.88 \%$. So the production of reed dry matter under natural conditions of the lower Liptov region reached $1.27 \mathrm{~kg} \mathrm{~m}^{-2}$, i.e. $12.7 \mathrm{tha}^{-1}$.

Table 2. Production parameters of Phragmites australis stalks

\begin{tabular}{|c|c|c|c|c|c|c|}
\hline \multirow{2}{*}{ Parameters } & \multicolumn{5}{|c|}{ Miniplots } & \multirow{2}{*}{ Mean \pm SD } \\
\hline & MP1 & MP2 & MP3 & MP4 & MP5 & \\
\hline Area $\left(\mathrm{m}^{2}\right)$ & 2.0 & 1.5 & 1.2 & 2.8 & 4.0 & $2.3 \pm 1.1$ \\
\hline Total fresh weight $(\mathrm{kg})$ & 4.67 & 3.00 & 2.81 & 8.59 & 16.45 & $7.10 \pm 5.72$ \\
\hline Fresh weight per unit area $\left(\mathrm{kg} \mathrm{m}^{-2}\right)$ & 2.34 & 2.27 & 2.34 & 3.07 & 4.11 & $2.83 \pm 0.79$ \\
\hline Weighted mean weight $\left(\mathrm{kg} \mathrm{m}^{-2}\right)$ & 0.30 & 0.17 & 0.18 & 0.73 & 1.88 & 3.26 \\
\hline
\end{tabular}

Thus established value of dry matter production of Common Reed can be considered quite high, especially from the aspect that it was a natural stand of Common Reed, without interference or intervention of a man, as well as from the aspect that the climate and soil-production conditions for the growth of Common
Reed are not optimal. Reed is a plant of warm climates but the studied area is in the climate district M5, which is characterized by less than 50 summer days per a year with daily maximum temperatures above $25^{\circ} \mathrm{C}$ and the July average temperature is less than $16^{\circ} \mathrm{C}$. It is also the climate district of the humid basins with mild winters. 


\section{Energy analysis of reed}

The combustion heat values determined for stalks, leaves and panicles of Common Reed are presented in (Table 3).

Table 3. Average values of combustion heat and ash of Phragmites australis species

\begin{tabular}{cccc}
\hline $\begin{array}{c}\text { Above ground } \\
\text { organs }\end{array}$ & $\begin{array}{c}\text { Weight } \\
\left(\mathrm{g} \mathrm{individual}^{-1}\right)\end{array}$ & $\begin{array}{c}\text { Combustion heat } \\
\left(\mathrm{J} \mathrm{g}^{-1} \text { d.w. }\right)\end{array}$ & $\begin{array}{c}\text { Ash } \\
(\%)\end{array}$ \\
\hline Stalk & 326.2 & 18,515 & 7.17 \\
Leaves & 146.4 & 18,786 & 8.81 \\
Panicle & 60.1 & 19,677 & 5.77 \\
\hline
\end{tabular}

The results show that the highest value of combustion heat was obtained for the panicles of reed, the arithmetic mean of which is $19,677 \mathrm{~J} \mathrm{~g}^{-1}$, leaves reached a value of $18,786 \mathrm{~J} \mathrm{~g}^{-1}$. Of individual parts of reed, the lowest combustion heat was recorded for stalks of the reed, which amounted to the average of $18,515 \mathrm{~J} \mathrm{~g}^{-1}$. The average value of combustion heat of Common Reed plant, determined as the weighted average of the individual parts of the plant, reaches a value of 18,721 $\mathrm{J} \mathrm{g}^{-1}$. In comparison with other energy phytomass species, this value can be regarded as more or less typical for this type of phytomass.

Calorific value calculated for dry phytomass is naturally lower by the heat value needed for water evaporation and amounted to $17,448{\mathrm{~J} . \mathrm{g}^{-1}}^{\text {. As a re- }}$ sult the total production of Common Reed phytomass represents $12.702 \mathrm{t} \mathrm{ha}^{-1}$ and its calorific value reaches $221.622 \mathrm{GJ} \mathrm{ha}^{-1}$.

These calculated values can be considered more in a theoretical level, as these figures refer to the absolutely dry biomass, which does not exist in real conditions as biomass is always burned with a certain moisture content. Humidity of the combusted material always decreases the fuel calorific value. Since the conditions of Common Reed phytomass burning are not known in advance, pertinent calorific values cannot be generally stated. As the calorific value directly depends on the water content of the biomass and of its composition, calorific value of air dried reed fluctuates in the range from 15,500 to $17,500 \mathrm{~J} \mathrm{~g}^{-1}$. From physical point of view and the possibility of comparison, combustion heat is the most important indicator.

\section{Biogas production of reed}

Energy biogas production is a widely-developed trend in the current bio-energy area. Therefore, a separate aim of the research was to determine the amount of biogas produced from the Common Reed phytomass. The average biogas production obtained from reed reached $351.311 \mathrm{~kg}^{-1}$ of dry matter. Of this biogas amount, methane $\left(\mathrm{CH}_{4}\right)$ accounted for $52.72 \%\left(185.211 \mathrm{~kg}^{-1}\right)$ what is lower than in case of Zea mays species equal to $55.5 \%$ (HuŤAN et al., 2007) and of Maramanthhus sinensis species, with a value of $61 \%$ (PospíšIL, 2013).

\section{Discussion}

When evaluating the Common Reed, it can be concluded that under natural conditions of the northern part of central Slovakia the production achieves 12 tonnes of dry matter per one hectare per a year. The energy equivalent of $221.622 \mathrm{GJ} \mathrm{ha}^{-1}$ represents by the simple conversion $5,293 \mathrm{~kg}$ of liquid hydrocarbon fuel (when considering the calorific value of diesel $41.87 \mathrm{MJ} \mathrm{kg}^{-1}$ ). Similar values for the production and calorific value of Common Reed, stated by Povraz et al. (2009) equal to 15-20 tonne and 17,000 $\mathrm{J} \mathrm{g}^{-1}$, respectively. This higher production can be justified by the lower soil quality of our research plot (land lying fallow). When converted for specific energy consumption $(\mathrm{kWh})$, the value of $221.622 \mathrm{GJ}$ is equal to $61,562 \mathrm{kWh} \mathrm{ha}^{-1}$. The total annual energy consumption of households converted per capita in Slovakia was equal to $4,944 \mathrm{kWh}$ in the year 2013 (ME SR, 2013). Energy 61,562 kWh ha ${ }^{-1}$ represents an annual consumption of energy for 12.45 inhabitants. Similar experiments were conducted previously also with Feedig Sorrel and different varieties of Amaranthus species. Feeding Sorrel is a hybrid of Rumex patientia L. (maternal line) and Rumex tianschanicu (paternal line) species and can be grown on conventional farmland, where it will last about 15 to 20 years (Maga and Piszczalka, 2006). For its cultivation, conventional agricultural equipment are used, however the soils waterlogged, stony, or acidic, with a $\mathrm{pH}$ below 5.0 , as well as soils poor in nutrients are not suitable for the establishment of energy plantations (PISZCZALKA and Maga, 2006). Since it is a perennial plant, in the second and subsequent years it must be fertilized and, where appropriate chemically protected against diseases and pests. Amaranth is a thermophilic dicotyledonous plant with high production of phytomass and seed with biologically valuable substances. However, it is high-demanding on light and seedbed preparation. At the variant with $100 \mathrm{~kg}$ of $\mathrm{N}$ fertilizer, a green production reaches $32 \mathrm{t} \mathrm{ha}^{-1}$ of dry matter with a calorific value of 10,000-12,000 J g ${ }^{-1}$ (PospíšIL, 2013).

Biogas production from the Common Reed is more effective than, for example, from grass silage $\left(200 \mathrm{~kg} \mathrm{l}^{-1}\right)$ or corn silage $\left(208 \mathrm{~kg} \mathrm{l}^{-1}\right)$ with a solids content of $40 \%$ (GoNDA et al., 2016), but higher production was recorded for varieties of Amaranthus species and Feeding Sorrel (MAgA and Piszczalka, 2006). Preliminary results indicate that the direct burning of Common Reed is more effective than the preparation of biogas, but the fermentation processes require a further study for determining the plant phase with the highest energy yield in the biogas preparation. 
For the purposes of phytoenergetics, only some perennial and multiannual plants are very important as generating sufficient amounts of total aboveground phytomass. The production of these plants is more efficient because it eliminates annually repeated cultivation, which is needed in case of annual plants (JANDAČKA and MALCHO, 2007). Unfertilized grasslands have also the potential for the purposes of phytoenergetics. As a source of energy there may be used also other herbaceous species of low feeding value growing in unfavourable production conditions (bedding meadows, waterlogged habitats).

\section{Conclusion}

Cheap kinds and forms of energy do not exist and probably they will not be discovered. So real and practical solutions at securing energy sources consist in assessment of each real usable source. The research in the past was focused on renewable energy sources in agriculture, and the production of such energy put high demands on soil quality and local conditions. Likewise the man cannot be dependent on fossil fuels and nuclear power which represent a great danger to the environment. A good example in this field is Germany being the today world leader in utilization of renewable sources of energy. Except for this energy security for the whole country economy, there is one important aspect - energy sources security for population, municipal and public sphere, where energy renewable resources can play an important role, mainly at regional level. This should become a state priority, as an entrepreneurial sector acquires energy by its own means. Therefore, any search of accessible energy sources needs meeting at least the minimum capacitive, energy, economic and environmental criteria, as these all act in significant synergies.

In mountainous rural areas there are, for example, opportunities to create jobs, not only in the use of pastures and meadows for livestock, but also in energy and/or phytomass production by special grown plants. It's a new phenomenon which has not been considered so far, but a lack of fossil fuels forces the man also to the use of these resources. In the agricultural holdings, agronomists can maintain grassland and preserve the production by means of silage for feeding their livestock or for energy production. Pasture and meadow vegetation compared to plants grown on arable land represents varied, multi-component plant communities, which are the result of ecological conditions, the level and way of management and spontaneous plant succession.

Furthermore, it has been established that the weather conditions in the Slovak Republic are highly unsteady. The fluctuation of meteorological elements reduces the production of traditional agricultural crops and just there is opening the space for applying biomass for energy production in Slovakia.

\section{Acknowledgement}

This work was supported by the project VEGA 2/0126/16 with a title of Research on the structure and dynamics of natural foci of tick-borne diseases mountain type.

\section{References}

Burnie, G., Forresterová, Sl, Greigová, D., Guestová, M., Harmonyová, M., Hobleyová, S., JACKSON, G., Lavarck, P., Ledgettoví M. McDonald, R., Macoboy, S., Molyneux, B., Moddie, D., Mooreová, J., Newman, D., North, T., Pienaar, K., Purdy, G., Silková, S.R., Ryan, Sl, Schienová, G., 2007. Botanika: ilustrovaný abecední atlas 10000 zahradních rostlin s návodem, jak je pěstovat [Botany: illustrated alphabetical atlas of 10,000 garden plants with instructions how to grow them]. Praha: Slovart. 1020 p.

DIN EN ISO 11734: 1998-11, Method by measurement of the biogas production.

Farkas, I., Tarnawa, A., Nyarai, F.H., Jolankai, M., 2009. Energy conversion of plant products. In Čelková, A. (ed.). 17. Posterový deň s medzinárodnou účastou a Deň otvorených dverí na ÚH SAV: Transport vody, chemikálii a energie v systéme pôda -rastlina - atmosféra, 12. november 2009. Zborník recenzovaných príspevkov - proceedings of peer-reviewed contributions [elektronický zdroj]. Bratislava: Ústav hydrológie SAV, p. 101-108.

Gonda, L., Gaduš, J., Kunskŕ, M., 2016. Bioplyn z trávnatej a d'atelinovej biomasy [Biogas produced from grass and clover biomass]. Agrobioenergia, 3 (2): $8-10$

HööK, M., Severtsson, A., Aleklett, K., 2010. Validity of the fossil fuel production outlooks on the IPCC Emission Scenarios. Natural Resources Research, 19, 2: 63-81.

Huťan, M., Kalina, A., Štifner, S., 2007. Bioplynová stanica na spracovanie cielene pestovaných pol'nohospodárskych plodín [Biogas station for processing purposefully cultivated crops]. Agrobioenergia, 2 (3): 5-8.

IEA, 2008. Key world energy statistics 2008, annually published statistics book. [cit. 2016-03-03]. http://www.iea.org/textbase/nppdf/free/2008/key_ stats_2008.pdf

JANDAČKA, J., MALCHO, M., 2007. Biomasa ako zdroj energie [Biomass as an energy source]. Žilina: Juraj Štefuň - GEORG. 78 p.

Kotrla, M.,PrČíK, M., 2012a. Miscanthus-potenciálna energetická tráva pestovaná na pol'nohospodársky nevyužívaných pôdach [Miscanthus - potential energy grass grown on disused agricultural soils]. In Podnikanie v Európskej únii. Obchodné právo EÚ II. Zborník príspevkov z medzinárodnej vedeckej konferencie. Nitra, 9. - 11. máj 2012. Nitra: 
Slovenská pol'nohospodárska univerzita. 1 electronic optical disc (CD-ROM), p. 68-76.

Kotrla, M., PrČÍK, M., 2012b. Zakladanie a ošetrovanie porastov Miscanthus na pol'nohospodárskej pôde južného Slovenska [Establishment and care of Miscanthus growth on agricultural land of southern Slovakia]. In Pestovatel'ské technológie a ich význam pre prax. Piešt’any: Centrum výskumu rastlinnej výroby, p. $57-60$.

Kotrla, M., PrčíK, M., 2013. Environmental and socio-economic aspect of growing Miscanthus genotypes. Scientific Papers. Series Management, Economic Engineering in Agriculture and Rural Development, 13 (1): 201-204.

Kotrla, M., PrČík, M., 2014. Growth dynamics of perennial energy grass genus Miscanthus studied in Slovakia. In SGEM 2014. 14th international multidisciplinary scientific geoconference SGEM 2014, 17-26, June, 2014, Albena, Bulgaria. GeoConference on Energy and Clean Technologies. Sofia: STEP92 Technology, p. 253-259.

Kováčoví, M., Kontriš, J., Kontrišová, O., 1999. An analysis of biomass production and energy equivalent of the Carex pilosa SCOP. population in a clear felling consortium of Fagus sylvatica reserve. Ekológia (Bratislava), 18: 333-340.

Kovéčoví, M., Schieber, B., 2002. Growth analysis and energy accumulation in above ground biomass of the population Galium odoratum (L.) Scop. (Rubiaceae) in submountain beech forest. Ekológia (Bratislava), 21: 15-26.

Kuklová, M., KuKla, J., 2009. Obsah energie v nadzemných orgánoch ostružiny malinovej (Rubus idaeus L.) v narušených a nenarušených smrekových ekosystémoch [Energy content in aboveground organs of raspberry (Rubus idaeus L.) in damaged and undamaged spruce ecosystems]. In ČERNOŠEK, Z., HolubOvÁ, J., ČERnOŠKOvÁ, E. (eds). 31. Mezinárodní slovenský a český kalorimetrický seminářr. Sborník př́spěvků. Pardubice: Univerzita Pardubice, 2009, p. 63-66.

Kuklová, M., Kukla, J., Šımková, I., 2014a. The changes of energy and carbon in top soil and aboveground part of Dryopteris filix-mas species along the succession of beech forest. Polish Journal of Ecology, 62, 2: 467-478.

Kuklová, M., HniličKová, H., HniličKa, F., KuKla, J., 2014b. Physiological reaction and energy accumulation of dominant plant species in fir-beech ecosystems affected by air pollution. Folia Oecologica, 41, 1: 53-61.

Kuklová, M., Kukla, J., Gašová, K., HniličKová, H., HNILIČKA, F., 2015. Vzt'ah ekologických podmienok k obsahu energie v listoch paprade samčej [Relationship ecological conditions of the energy content in the leaves of ferns male]. In ČERNOŠEK, Z., HoLubová, J., ČERnošKová, E. (eds). 31. Mezinárodní slovenský a český kalorimetrický seminár̆. Sborník př́spěvkü. Pardubice : Univerzita Pardubice, 2009, p. 95-98.
Maga, J., Piszczalka, J., 2006. Biomasa ako zdroj obnovitel'nej energie [Biomass as an energy renewable source]. Nitra. Slovenská pol'nohospodárska univerzita. $108 \mathrm{p}$.

ME SR, 2013. Energetická politika Slovenskej republiky (Návrh), September 2013 [The energy policy of the Slovak Republic (Draft), September 2013]. [cit. 2016-09-02]. www.economy.gov.sk/navrh-energetickej-politiky-sr-hzj/141392s

Piszczalka, J., Maga, J., 2006. Mechanizácia výroby a využitia biomasy [Mechanization of production and use of biomass]. Nitra: Slovenská pol'nohospodárska univerzita. $116 \mathrm{p}$.

PospíšIL, R., 2013. Pestovanie láskavca (Amaranthus) na výrobu bioplynu [Growing of amaranth for the biogas production]. Pôdohospodársky poradenský system [cit.2016-03-09]. http://www. agroporadenstvo.sk/rastlinna-vyroba-energetickerastliny? article $=202$

Povraz, P. NašČÁKová, J., Kotorová, D., Kováč, L., 2009. Pol'né plodiny ako zdroj biomasy na energetické využitie v podmienkach Slovenska [Field crops as a source of biomass for energy use in Slovakia]. In Inovativne technológie pre efektivne využitie biomasy $v$ energetike. Zborník príspevkov z medzinárodnej vedeckej konferencie. 18. - 20. november 2009, Zemplínska Šírava. Košice: Ekonomická univerzita v Bratislave, Podnikovohospodárska fakulta so sídlom v Košiciach, p. 66-75.

PrČík, M., Kotrla, M., 2015. Targeted cultivation of the energy plants in conditions of the Slovak regions. Scientific Papers. Series Management, Economic Engineering in Agriculture and Rural Development, 15, 1: 399-404.

STN EN 14918: 2010 (65 7410), Tuhé biopalivá. Stanovenie výhrevnosti [Solid biofuels. Determination of calorific value].

Suslick, S.B., Machado, I.F., 2004. Non-renewable resources. Natural resources policy and management. In Encyclopedia of life support systems. Oxford: Eolss Publishers. [cit. 2016-03-05]. http:// www.eolss.net

SÝKora, A., Kuklová, M., Kukla, J., 2009. Vplyv svetelného faktora na obsah energie $\mathrm{v}$ nadzemnej fytomase druhu Rubus hirtus Waldst. et Kit. vo vybraných bukových fytocenózach [A light impact factor on the energy content of the aboveground phytomass of Rubus hirtus Waldst. et Kit. in selected beech phytocoenoses]. In MARUŠKová, A., VANEK, M. (eds). Ekológia a environmentalistika. Zborník príspevkov doktorandov zo 6. Študentskej vedeckej konferencie. Zvolen: Technická univerzita vo Zvolene, p. 101-105.

VDI 4630: 2006, Fermentation of organic materials characterisation of the substrate, sampling, collection of material data, fermentation tests.

Received June 6, 2016 Accepted November 10, 2017 